\title{
Sustainable human resource management as a driver in tourism policy and planning: a serious sin of omission?
}

Tom Baum

University of Strathclyde, Glasgow

\section{Abstract}

This paper focuses on the neglect of an employment or workforce focus in policy engagement and planning for sustainable tourism. Tourism is of interest here because there is an established role for government and the private sector in policy engagement and strategic planning with respect to product development, infrastructure, marketing and human resource capacity and the focus has increasingly emphasized sustainable goals within this process. The discussion addresses the central role of people and work within concepts of sustainability and sustainable communities and questions why this has been, substantially, ignored in tourism. The paper starts by recognising the interconnectedness of employment in tourism and its workforce concerns with a wide range of inter-linked policy and operational considerations. This, in turn, points to the utility of the sustainable HRM model as a means by which to frame tourism work. Thereafter, this paper introduces new approaches through the proposal of sustainability indicators that have both theoretical and practical policy formation value in relation to the workforce. These Sustainable Employment Capacity (SEC), Service Delivery Capacity (SDC) and Service Quality Capacity (SQC) with which policymakers can gauge their readiness for sustainable growth in tourism employment. The research and application implications for this approach are discussed. 
Keywords: tourism work; sustainable tourism; sustainable HRM; workforce planning; tourism policy 
$\underline{\text { Introduction }}$

This paper addresses a key driver within sustainable tourism that is widely neglected or underplayed within both practitioner and academic discourse. As 2017 is the International Year of Sustainable Tourism for Development, this represents an opportune time to address this neglect. The area in question is the tourism workforce and associated employment issues from a sustainability perspective. This discussion identifies limited policy goals seeking sustainable outcomes in tourism and widespread practice with respect to the workforce and employment. The paper further recognizes that workforce and employment issues in tourism cannot be interpreted without reference to the wider social, cultural and economic context within which they are identified. The focus of discussion in this paper is on tourism because it represents an industry where policy engagement and strategic planning through collective government and/ or the private sector endeavour is commonplace at a local, regional and national level, planning that incorporates product development, infrastructure, marketing and human capacity development. There is growing evidence of bespoke human capacity development planning for tourism at national and regional levels (see, for example, Human Science Research Council, 2017 in addressing strategic human resource and skills challenges in South Africa) but there are also severe limitations to the impact of such interventions (Solnet et al, 2014). The specific focus here is on tourism at the level of the destination but the implications of the analysis also can extend wider within other commercial services such as retail.

Sustainability and sustainable development are, of course, contested concepts (Christen and Schmidt, 2011; Waas et al, 2014) but all definitions broadly coalesce around a number of key components or principles (Waas et al, 2014) that include equity (inter/intra 
generational, interspecies, geographical, and procedural); process dynamics and the recognition of constant change; integration of the interests of the various stakeholders of sustainability; and normativity which recognizes the social constructs that underpin sustainability. In this paper, reference is made to an understanding of sustainability and sustainable practices that acknowledge all of these principles. They reflect sustainable approaches to the natural and social environment and its stakeholders within the specific context of tourism employment that have a focus on long-term outcomes and benefits and avoid short-termism in thinking and application. This enables us to utilize the concept of sustainable HRM in tourism as underpinning the main arguments presented here. The paper explores seeming neglect of workforce considerations within the sustainable tourism policy narrative and, as a response, proposes measures of workforce readiness, in both quantitative and quality terms, for application within tourism.

This paper draws together a number of conceptual strands that have not traditionally been linked together within and between both sustainable tourism and the workforce/ employment domain. This presents opportunity to test uncharted conceptual waters. The paper is organized as follows. The first part gives consideration to workforce issues in tourism from a strategic and destination policy and planning perspective and assesses why such discussion has largely been marginalized. A specific concern of this paper, the limited consideration of the workforce within debates about sustainable tourism, is then introduced and is framed by a key driver in this debate, the emerging field of sustainable HRM which has had a limited impact on discourse about tourism employment. This then leads to proposals of measures to facilitate a sustainable approach to the workforce that is 
both ethical and practical. Finally conclusions are drawn and recommendations to policy makers and academic researchers are proposed.

The workforce in policy formulation and planning for tourism

This paper advocates for critical consideration of the workforce within policy formulation and the planning process for sustainable tourism, focusing on front-line employment. It is contended here that this topic has been largely marginalised in the minds of policy makers and academics alike. Critically, it is argued that little has changed in the narrative about this topic over the past 25 years (see for example, Cobble, 1991; Glenn, 1992 for assessments of historical perspectives on service work; also Baum 2007; 2015; Bal and de Jong, 2017). In part, this has moved forward with some recognition of the International Labour Organization's (ILO) notion of decent work (ILO 2012) as well as Article 8 of the UN's 2030 Agenda for Sustainable Development (United Nations 2015).

Much tourism employment includes work which is poorly paid, and lacking in social respect and value (see, for example, Robinson, 2013; De Beer et al, 2014); hostile to workplace organisation (Bergene et al, 2015); or is located in an environment where employer practice flies in the face of both legal and ethical standards and expectations (Poulston, 2008; The Guardian, 2016). It is also widely described as 'low skills' (see Shaw and Williams, 1994; Wood, 1997; Westwood, 2002; Ladkin, 2011 among others) although this is challenged as western-centric by other authors (Baum, 1996, 2002, 2006; Burns, 1997; Nickson et al., 2003). However, Knox et al (2015) recognise inherent ambiguity with respect to interpretations of job quality in the sector - what may be perceived as a 'bad' job from an external perspective may be seen entirely differently by those involved in the work. It is arguable that perceived quality of work in tourism is contingent on the macro-context 
(economic and socio-cultural) in terms of, for example, gender and ethnicity (see Adler and Adler, 2004; McDowell, 2007) as well as that of the attitude and aspirations of the individual in assessing the relative job opportunities available within the sector (Gursoy et al, 2013).

There is growing recognition of ineffectual engagement with workforce issues in the tourism policy and planning (Solnet et al 2014; Baum et al 2016a) and, arguably, also in the priority it is accorded by practice in the private sector. Solnet et al's (2014) study of workforce development relating to tourism examined policy-focused public documentation drawn from over a 12 year period (2000-2012) relating to Australia (24 items) and Scotland (34 items). Their analysis is probably the only attempt to systematically address labour market or workforce policy in tourism over a longitudinal time frame or on a comparative basis, although others have looked at policy relationships in this area in a rather more limited sense (Baum, 1994; Esichaikul and Baum, 1998; Baum and Szivas, 2008). The Solnet analysis highlights outcomes that are a concerning indictment of the failure of policy development in this area. This paper pinpoints a number of concerns, including the diversity of agencies engaged with workforce analysis, varied methods employed to reach conclusions, repetition of concerns and recommendations in reports issued over time, a lack of accountability for or follow-up to recommendations and limited evidence of impact on policy or practice with regard to the reports published. Policy makers are not alone in their limited and/ or ineffective consideration of workforce themes with respect to tourism. Baum et al (2016a), in a ten-year review of the leading academic journals in tourism and hospitality, highlight what they argue to be serious neglect relative to the importance of the area and further posit that the research that has been published suffers from issues of theoretical and conceptual quality; approaches that are piecemeal in terms of scope, topics 
and methods; and are overly managerialist in seeking practical solutions rather than wider explanations for identified phenomena.

Before building upon this concern about the neglect of effective sector workforce research and planning in tourism, it is worthwhile to ask whether tourism is alone as an industry that all but neglects an effective sector-based and integrated approach to workforce planning. Tourism's multi-unit, geographically dispersed and highly diversified profile in most countries does not make such tasks easy to accomplish and, indeed, effective sector workforce planning may be an unrealistic aspiration for tourism. However, tourism workforce planning, superficially at least, is reasonably effective in its execution but less so in its outcomes and impact in many countries. Comparison with other industries is illuminative. A review of a range of these, within the commercial service sector and beyond, provides no evidence that macro-level research-informed workforce planning is widely prevalent in the private sector or, indeed, within much of the public or third sectors.

An exception may be the health care and elder care sectors which are complex industries that encompass workforce diversity (Martin and Young, 2008; Rubery et al, 2011), geographical spread (Larsen and Lauxen 2014) and skills segmentation (Ono et al 2013) and where a clear relationship to public policy concerns is evident. Health and elder care are also sectors that, in most countries, are closely aligned with government policy and funding, either directly or indirectly. Therefore, leadership in workforce planning for health is widely seen as a public sector responsibility (Crettenden et al 2014). Policy debate in this area is also robust (Birch et al 2013; Birch et al 2015). The workforce issues faced in the elder care sector, interestingly where operations are commonly located within the public, private and third sectors, appear to mirror many of those encountered in tourism, notably in terms of high labour turnover and recruitment challenges (Howe et al, 2012). Evidence, however, 
does not suggest that the planning process contributes effectively to overcoming skills shortages in the health or care services of major developed countries (Birch et al, 2013).

Evidence from other private ownership economic sectors is more limited, begging the question as to why tourism should require a different and planned response. Retail is, in many respects, a sector that has HR issues in common with tourism but, here, discussion of workforce issues is largely confined to operational (Booth and Harmar, 2007; Hart et al, 2007) or change-driving considerations (for example the impact of Generation $Y$ on the retail workforce) (Broadbridge et al, 2007) or the effects of automation/ robotisation (Gallouj et al, 2015; Jee, 2016). Retail work in its social context (for example, Ruetschlin, 2013) is probably as far as the policy-informing narrative goes. Government leadership with respect to workforce policy in retail is not really evident.

In part, the answer to the specific conditions in tourism lies in the role of government and government agencies in planning growth within tourism at a national and regional level, frequently targeting specific outcomes in terms of visitor numbers and spend. It is also a reflection of the fragmented nature of the industry, operating across both the formal and informal economies of most countries and frequently facing structural challenges through seasonality. These factors, unusual in other areas of the economy, are perhaps the strongest justification of a planned approach to the workforce that integrates with wider performance outcomes (Baum and Szivas, 2008).

This review thus far points to issues with respect to thinking about the workforce in the context of tourism, highlighting a failure for the debate to progress policy development and for quality research studies to be scarce, poor quality and managerialist. This paper argues for alternative approaches to conceptualising workforce themes in sustainable tourism planning and for the adoption of new approaches to underpin these processes, 
drawing on the principles of sustainable HRM. These approaches may include recognition of the role of the employee/ workforce in delivering sustainable products and services; engagement with the wider social and economic context affecting the workforce; exploration of capacity and capability constraints that the workforce/ labour market can impose on a location's ability to deliver these products and services in a sustainable manner; and engagement with the tenets of 'decent work' in tourism.

Before moving on to address wider issues of sustainability in tourism and what they may contribute to our understanding of the workforce, it is necessary to recognise that such work does not exist in a vacuum and continues to change in consort with wider social and economic developments within society. This is now addressed in terms of the changing nature and context of tourism work.

\section{The changing context of tourism work}

Interrogation of the tourism workforce literature generally fails to consider work quality concerns within a wider policy context and this is a severe limitation. Much discussion is inward looking and addresses issues and themes from the perspective of employers and, as such, is predominantly managerialist in focus (Baum et al 2016a). Therefore, Andriotis and Vaughan $(2004,67)$ are correct in highlighting that, in the context of tourism employment, "some of the underlying assumptions and inter-relationships are rarely, if ever, discussed". They highlight the importance of the wider context affecting tourism employment and policy by raising questions as to "whether the characteristics of tourism jobs are really good or bad and whether addressing them as problems is always the correct way forward". 
The challenge, as Bartlett et al (2016) highlight, is that individual organisations and the sector within which they are located tend to focus on those areas of linkage in the external environment that are perceived to offer the greatest threats and opportunities. The arguments developed by Jithendran and Baum (2000) support this position, with a focus on the operational focus that underpins human resource issues at the policy and planning level in tourism, leading to ad hoc and fragmented responses. Certainly, the evidence assessed by Solnet et al (2014) points to relatively limited and uncritical engagement with policy across the wider environment and, where such linkages are evident, they tend to be time-reactive, responding to headline economic, social or market changes (such as the Global Financial Crisis in 2008).

Therefore, it is argued here that there is a need to look outwards at the society within which tourism work is located in order to understand the multiple policy linkages within the employment framework as the basis for a more meaningful search for explanations and the formulation of policies and practices that can affect change. For illustrative purposes, these relationships are represented in Figure 1, which represents the complex eco-system within which tourism employment, at a destination level, is located and the interdependencies that exist with that wider economic, social and cultural environment. Conceptualised by the author from an extensive review of labour market, destination and tourism literature, these relationships are not intended to be exhaustive and their relative significance will vary greatly from destination to destination. Andriotis and Vaughan (2004), for example, highlight what they call pluriactivity in tourism employment in their case study environment of Crete across a number of sectors but particularly in relation to agriculture where seasonal demand for labour complements that within tourism, highlighting the need to co-ordinate policy between these sectors within the labour market. 


\section{< Figure 1 approximately here>}

The linkages illustrated in Figure 1 are indicative and could be extended to address the workforce in the context of skills changes and immigration policy (IOM 2005; Kirkegaard 2007); migrant labour and mobilities within tourism work (see, for example, Joppe 2012; Janta et al 2012; Duncan et al 2013; Baum 2013); and gender (Baum 2013). This contextualisation of the tourism sector in this paper also gives particular nuances to, for example, career choices and destinations (Kong et al, 2012) and the role that training for the sector plays in launching diverse careers and providing portable and transferable skills which have application across a wider range of sectors (Okumus et al, 2016). Dinica (2009, 583-4) highlights the major role that government and related public agencies play in creating and supporting such joined-up thinking in policy formation, noting the competencies across a wide range of areas that impinge on tourism "such as spatial planning, infrastructural development, fiscal policies, transport policies, labour policies and water management".

The policy linkages, of course, can work in other ways so that the skills demands of a sector such as tourism can act as a major driver of policy with respect to wider labour market, educational and national human resource development (NHRD) considerations (McLean, 2004, 2012; Lynham and Cunningham, 2006; Gangani et al, 2006). The notion of NHRD aligns well with thinking in this paper, as articulated by McLean $(2004,269)$ in arguing that NHRD "goes beyond employment and preparation for employment issues to include health, culture, safety, community, and a host of other considerations that have not typically been perceived as manpower planning or human capital investment." Such sentiments accord with the arguments of, among others, Garavan and McGuire (2010) and 
Kuchinke (2010) in expanding the aims of NHRD to include less economically-focused considerations, including the planning of education systems at vocational, higher and postexperience levels (Rana and Ardichvili, 2015).

The workforce also needs to be considered from a future perspective, notably in the context of labour market polarisation between low and high skills positions in many developed economies (Solnet et al 2015). UKES (2014, v) highlight this when they forecast growth in relatively high and low skilled jobs.

Growth is projected in high level occupations (managers, professionals, and associate professionals) and some lower skilled occupations (in caring, hospitality and leisure).........This has implications for career progression without middle-level occupations, individuals may find it more difficult to progress from low to high skilled jobs".

The trend towards polarisation in the labour market is noted across developed economies by Autor and Dorn (2009) who focus on the growth of low skills service jobs in the US, Goos and Manning (2007) in the context of jobs in the UK and Goos et al (2009) in their analysis of the European environment. The consequences of this polarisation can already be seen in the elimination of many middle management roles within the hospitality and wider tourism sector. This is affirmed by both Rajan and Wulf (2006) and Solnet et al (2015) who also return to what they describe as an ongoing trend towards organisational flattening at all levels, creating demand for increased empowerment at the front-line. What has changed, from a contemporary perspective, is the ongoing impact of technology on workplace processes, practices and power relationships. 
This discussion now moves forward to consider how the growing debate on sustainable tourism can, perhaps, contribute to understanding of its workforce in a contemporary context.

\section{Sustainability, sustainable development and sustainable tourism}

So where does sustainability, sustainable development and, critically, sustainable tourism locate within this discussion? There is a growing interest in what Rimanoczy and Pearson $(2010,11)$ describe as the "new world of sustainability" in the context of human resource management at the level of the firm, implying a shift in how organizations identify, recruit and develop their current and future employees. Their argument is that for change towards more sustainable practice to emerge in these areas requires fundamental change in organisational culture and leadership, driven by ethical and wider CSR considerations. This discussion at the level of the organisation can also incorporate acknowledgement of a number of related themes including the evolving nature of psychological contracts and the ways in which employees and employers are bound together (Coyle-Shapiro and Kessler, 2000; Lub, et al., 2012); recognition of the importance of sustainability within organisational leadership (Hargreaves and Fink, 2006; Ulrich and Smallwood, 2013); and understanding of mutual responsibilities through seeking work-life balance (see, for example, Darcy et al, 2012; Fujimoto et al, 2013; Lee et al, 2015 ).

However, in terms of sustainable tourism, workforce themes do not feature as prominent considerations. On the face of it, the UNWTO's (nd) definition of sustainable tourism provides opportunity to clearly articulate its implications for the workforce and employment. This is that sustainable tourism is "Tourism that takes full account of its current and future economic, social and environmental impacts, addressing the needs of 
visitors, the industry, the environment and host communities". However, Miller et al (2010) address the reasons for the emergence of sustainable tourism as a concept, linking it to a combination of the growth of tourism, the intentions behind political discourse that has become more environmentally focused and awareness of the meaning of the principles of sustainability. No mention is made of employment or workforce-related themes. However, sustainability has become a constant feature of tourism policy at all territorial levels - as Torres-Delgado and Lopez Palomeque $(2012,1)$ note:

Institutional policies and initiatives have advanced gradually from an initial acceptance of sustainability in tourism associated almost exclusively with the conservation of the environment, to a more global concept which takes the balance between society, the environment and economy into account.

This extension of the concept of sustainability from the natural to include the social environment (as recognised by UNWTO) is evident in wider discussions about sustainable development (Axelsson et al, 2013). Discussion of sustainable tourism, therefore, has been slow to engage with ideas about sustainable human resource management as a means by which to address the evident issues that can be seen within sector employment and its workforce. Discussion now moves on to consider how this contribution can be harnessed.

\section{Sustainable HRM}

The relative neglect of workforce considerations within discussions relating to sustainable tourism policy is somewhat incongruous, given that social, cultural and community-driven factors figure prominently in some (but not all) analyses of this area. This neglect is all the more surprising in light of the leadership provided by international 
agencies, notably ILO's notion of decent work (ILO 2012) and the clear guidance provided by Article 8 of the UN's 2030 Agenda for Sustainable Development which advocates "full and productive employment and decent work for all" (United Nations 2015). Both of these invectives are intended to inform and shape the policies of governments, agencies and the private sector and, as such, provide a valuable framework by which to guide the macro perspective of tourism work that is the focus of this paper. Sehnbruch et al (2015), interestingly, note the far wider recognition and adoption of the contextualized United Nations approach as compared to that of the much narrower focus of the ILO's decent work. The emergence of sustainable HRM as a conceptual framework can be linked, at an organisational level, with growing interest in the full breadth of dimensions within contemporary interpretations of Corporate Social Responsibility (CSR) (Tisdell, 2000; Ehnert and Harry 2012; Cohen et al, 2012; Voegtlin and Greenwood, 2016) and wider recognition of the value in executing business strategies for sustainability through the design and implementation of human resource management practices (Buller and McEvoy, 2016).

Ehnert et al $(2016,90)$ define sustainable HRM as " the adoption of HRM strategies and practices that enable the achievement of financial, social and ecological goals, with an impact inside and outside of the organisation and over a long-term time horizon while controlling for unintended side effects and negative feedback". Ehnert (2009) identifies the key components of sustainable HRM practice as attracting and retaining talent and being recognised as an 'employer of choice'; maintaining employee health and safety; investing into the skills of the workforce on a long-term basis by developing critical competencies and lifelong learning; supporting employees' work-life balance and work-family balance; managing aging workforces; creating employee trust, employee trustworthiness and sustained employment relationships; exhibiting and fostering (corporate) social 
responsibility towards employees and their communities ; and maintaining a high quality of life for employees and communities

By any token, these attributes are the core components of good employment (or decent work) which, when amalgamated into both the practice and culture of an organisation, can help to achieve sustainability outcomes. Anticipating the emergence of sustainable HRM in tourism, Baum (2006:290-291) provides a comprehensive comparison at the organisational level between what he describes as "old human resource practice" and the features of a "sustainable human resource paradigm" in the context of tourism, spanning indicators ranging from operational considerations through to the level of labour market planning but not addressing policy implications. As with much of the narrative relating to sustainable HRM, both Baum and Ehnert focus on its application at this organisational level, affirming its value in the words of Lange $(2016,918)$ when he says that "Sustainable HRM ...... can become an alternative business purpose; one that legitimises business activity within society and with other stakeholders, including investors."

Sustainable HRM, therefore, is intended to be a proactive approach that recognises the value of "developing mutually beneficial and regenerative relationships between internal and external resource providers (e.g. employees, their families, education systems, natural environment)" (Ehnert et al, 2016, 90). It also needs to be understood in terms of the standards that are implicit in its application alongside multiple, potentially contradictory, economic, ecological and social goals such as human or ecological sustainability as well as the complex interrelations between HRM systems and their internal and external environments. Incorporating the wide range of good practices articulated by Baum (2006), Ehnert (2009) and Liebowitz (2010) in accommodating the needs of the individual within organisations "the argument is that fostering the sustainability of the HRM 
system itself becomes a 'survival strategy' for organisations dependent on high quality employees" (Ehnert and Harry, 2012, 223).

An alternative approach (and one that accords with the arguments in this paper) is to look at sustainable HRM in terms of wider societal contexts and policies (Scully-Ross, 2012), for example by reference to the local, regional or national workforce. Ehnert and Harry $(2012,223)$ acknowledge the policy linkages that underpin a wider view of sustainable HRM in noting the impact "of scarce human resources, of aging workforces and of increasing work-related health problems" on the communities within which work takes place.

Translating the principles of sustainable HRM into policy at a national or local level presents challenges that are, perhaps, difficult to implement within the dominant neoliberal ideology of many governments. At a macro level, employment policies that embrace sustainable principles may be reflected in the legal and moral framework that provides the architecture for 'decent work' - relating, inter alia, to dignity and respect at work, working conditions, employment rights and protections, rights with respect to collective representation, opportunities for personal growth and access to fair remuneration for the work undertaken, often framed as a minimum or living wage (Gregg et al, 2016; Zeng and Honig, 2016).

Sustainable HRM, by definition, also acknowledges the possibility of unsustainable HRM (Kramar, 2014) through practices that cannot be sustained at an organisational level and may lead to, for example, burnout through individual stress, other forms of illness or high levels of attrition. In the context of tourism, these are commonly manifested and are dimensions of the workforce that are addressed by Boardman et al (2015) in their analysis of decent work in the full tourism value chain. Likewise, Davidson and Wang's (2011) study concludes that the tourism industry does not plan for sustainable labour practices and 
employee retention, noting that casualization is the dominant strategy employed to cope with changing demand for labour. However, there is emergent tourism sector interest in the practical benefits of adopting a sustainable approach to workforce management as evidenced in Perry (2013). As a corollary to this in terms of academic research, Baum et al (2016b) represents probably the first scoping exercise of the application of sustainability principles to a range of workforce issues in tourism. Their review addresses perspectives from the standpoint of human rights, gender, mobilities and migration, age and generations, careers and career competencies, education and training, and models of social enterprise. Baum et al's (2016b) contribution is to recognise the intersectionality of sustainable HRM with tourism against a wide range of perspectives (and their coverage is not comprehensive) and this thinking provides and important underpinning to this paper.

In many regards, the principles that underpin sustainable HRM directly confront and provide potential remedies to the challenges and issues that face employment in the tourism sector. Sustainable HRM provides a framework whereby the neglect of workforce considerations in tourism can be addressed. At both a policy and practice level, the tourism industry faces challenges with regard to attracting the best possible workforce, retaining them within the sector, remunerating employees in a way that competes with other industries, providing the workplace environment for 'decent work' and offering progressive developmental and career opportunities. These are issues that may be alleviated by stakeholders in the private and public sectors through the adoption of a sustainable HRM 'mind set' and applying the key tenets that emanate from this mind set to employment rather than adopting project-oriented, reactive and short-term measures in addressing these issues. This is easily said but implementation may be more challenging. The remainder 
of this paper will explore one policy-informing option as a way forward with respect to this conundrum.

The discussion thus far has sought to tie together disparate strands as a basis for understanding why workforce themes are frequently poorly represented within sustainable tourism policy formulation and, as a consequence, why (based on the professional experience of the author) workforce considerations are rarely major drivers in shaping key decisions in tourism practice and investment. The evidence appears to support the view that tourism policy making, where it does address workforce themes, is fragmented and makes inadequate reference to the complexity of wider policy considerations. Sustainability is a dominant influence on the contemporary tourism policy narrative but, it is arguable, this discussion has been 'hijacked' by those advocating for concerns about the natural environment in a tourism context. As a consequence, what should be a key theme within sustainable human ecology in tourism, the workforce, has been largely side-lined. The emergence of sustainable HRM as a distinct field offers an opportunity to bridge some of these gaps at a conceptual and practical level and, potentially, may enable the policy narrative at a policy level to move forward in a way that is theoretically and methodologically sound and makes a practical difference. One such route is explored in the next section to this paper by introducing an array of conceptual tools by which to link economic development in tourism with its implications for the workforce environment at a strategic level.

\section{Finding a way forward}

This way forward, in unravelling the disparate elements of the above discussion, requires that the policy process and its underpinning research challenge the status quo with 
respect to tourism's workforce at a destination/ national level. To do this, it is important to articulate clearly what information and analysis is required in order to attain tourism and wider social and economic goals and, indeed, to the interdependencies between them that are proposed in Figure 1. This process can be driven by asking a series of questions about the tourism development policy and planning for a location and the facilitating workforce environment that exists alongside such development, both in terms of the current situation and the desired future position. Some of these questions may be raised in policy discussions about sustainable tourism but not in this systematic format. The answers to the question posed in Figures 2 and 3 can play an important policy-informing role in relation to tourism and, specifically, its workforce and, equally important, provide the basis for an on-going research agenda. The questions can play a valuable role as part of the agenda for discussion by governments, Destination Management Organisations (DMOs), private sector and civic society stakeholders as part of the tourism policy formulation and planning process. These questions have the potential to frame a route map that addresses these issues and shapes a more meaningful and sustainable approach with regards to the development of workforce policies for tourism. As noted, they can also frame the basis for a valuable academic research agenda. Such questions could include an assessment of the current state of the destination with respect to 'workforce readiness' as suggested in Figure 2:

- To what extent does the national agenda recognise the value of 'decent work' through legislation and wider political leadership?

- What are the 'decent work' issues facing tourism and the wider economy in the destination region?

- Where do tourism and tourism employment sit within the wider economy of the destination region and what competition does the industry face in labour market terms? 
- What is the current tourism business profile of the destination - numbers, revenue, per passenger expenditure, markets, product, services?

- What is the current quality profile of service providers in the destination?

- What is the current human resource capacity (numbers, skills, origin, diversity) in the destination that is delivering the existing range of tourism products and services?

- What products and services can the destination deliver with these human resources (the service delivery capacity) - measured in terms of room nights, tours, dive groups etc.?

- At what level/ to what standards can the existing workforce deliver these products and services (the service quality capacity)?

- What do indicators relating to productivity, service quality and visitor satisfaction tell about the existing workforce?

\section{Figure 2: Indicative questions to be asked: Where we are now with respect to 'workforce} readiness'?

The corollary to a current assessment of 'workforce readiness' is to ask questions

about the likely impact of change with respect to tourism product and markets. Such questions could include an assessment of the anticipated state of the destination in line with development plans with respect to 'workforce readiness' as suggested in Figure 3:

- To what standards, in terms of employment and the achievement of 'decent work' for all, does the destination aspire?

- What are the destination's tourism business development targets - numbers, revenue, per visitor expenditure, new and existing markets, product, services?

- What quality standards and market ' $\mathrm{mix}^{\prime}$ does the destination aspire to achieve for its tourism products and services?

- What is the human resource shortfall - both in terms of numbers and skills (by vocational/ professional areas) representing service delivery capacity and service quality capacity gaps?

- What needs to be done to close these gaps in terms of recruitment (home, abroad) and training?

- What are the destination location infrastructure gaps - in Technical and Vocational Education and Training (TVET), colleges, universities?

- How long will it take to develop the required workforce to eliminate the two gaps?

- What are the political, economic, cultural, social, environmental and technological 
constraints on closing these gaps?

Figure 3: Indicative questions to be asked: Where we are going in the future with respect to 'workforce readiness'?

These questions are complex and interrelated and are, essentially, designed to shift the focus of policy making and planning away from a dominant market and facilities focus to a more balanced agenda. Profiling the workforce in terms of the above questions has the potential to shape the nature of tourism development relative to these drivers but also to constrain such development. Unambiguous answers to these questions, therefore, can create an entirely new dynamic within planning and decision making where workforce capacity, quality and sustainability questions are raised as a starting point to the framing of plans rather than as an afterthought. Addressing these concerns can, for example, challenge widespread inconsistencies which sees governments promoting both tourism as a growth sector and decent work as part of their international obligations in the full awareness that a fast-growing tourism industry has a very mixed record in delivering such 'decent work'.

The University of the Aegean (2002, xii) locate the value of setting capacity limits to tourism development as supporting "a vision about local development and decisions about managing tourism". This is at the nub of the argument promulgated here. It is about recognising that the characteristics of the local labour market and the work environment within it may constitute a major determinant of what a destination can deliver to its visitors. Baum et al $(1997,222)$ put it like this;

The make-up of the local workforce (or that which can be introduced into the local environment) has a direct influence on the standards and character of the tourist offering which can be prepared and presented to visitors. 
In applying the notion that there are ethical, capacity and capability constraints that relate to the tourism labour market, then, we can derive three key concepts as indicators of destination capacity (resort, city, region, country). These draw broadly on the idea of applying ethical and capacity principles to the workforce. The concepts reference the following:

- Is the tourism industry able and willing to deliver ethical employment of a quality and sustainability that enables it to meet social objectives relating to 'decent work' and fair remuneration? Answering this question recognises that tourism employment does not exist in isolation but must be evaluated against competing sectors in the national and regional economy as well as in terms of commitments to social policy and international obligations. Sustainable Employment Capacity (SEC) is the extent to which such standards are recognised and addressed in tourism policy and planning, based on a systematic analysis of policy relations across a range of social indicators.

- Are there sufficient employees available and willing to deliver tourism's products and services to the destination's visitors? Can the destination access sufficient labour from within its own communities or from external sources (by means of internal or external migration) to meet the needs of tourists who visit? Answering this question introduces the notion of a destination's Service Delivery Capacity (SDC) which is based on the number of visitors to a destination at any given time and a numerical count of the workforce required to deliver services to these visitors through the diversity of businesses and facilities that make up a complex industry. This calculation may be without reference to varied staffing levels that are required to deliver service in different types of operations and at different times (of the year, 
day) but, more realistically, needs to accommodate average productivity standards across the sector (and how these can be enhanced through training) and the changing technologies that evolve to support and/ or replace labour.

- Do the industry's employees have the appropriate skills to deliver the products and services at quality standards that meet the expectations of the destination's visitors? Answering this question, complementarily, introduces the notion of a destination's Service Quality Capacity (SQC) which is based on the quality and/or productivity standards set for a destination and reflects the skills available through the education and training system to the tourism industry across all sub-sectors and vocational/ professional areas.

SEC, SDC and SQC, then, are concepts that can enhance a destination's ability to monitor current policy, planning and decision-making at a micro- and macro-level within tourism. At a micro-level within organisations, these indicators can assist in practical decision-making - can a hotel meet the needs of specific national groups or are additional language skills required? Can the kitchen brigade deliver in technical terms on the demands of new menu items planned? At a macro-level, monitoring, among other things, visitor feedback can ascertain whether the destination has issues with respect to SEC or SDC, or SQC or, indeed, all of them. The utilisation of SEC, SDC and SQC as guiding concepts, it is argued here, is also at the heart of a sustainable approach to addressing workforce issues in a way that is principled, realistic, forward-looking and designed to maximise input from the local labour market while also ensuring that the workforce contributes effectively to destination development objectives. 
Where these concepts have maximum utility is in support of future policy, planning and decision-making at the macro-level within tourism. Using them may allow key workforce capacity considerations to be asked alongside the policy, planning and investment targets that are set with respect to market growth, product developments and service enhancements. In this way, workforce considerations can play a defining role in shaping policy and planning across these key areas. Applying ethical principles and recognising capacity limits in this context may lead to any or all of the following actions at the destination level:

- Limiting growth in visitor numbers until additional and appropriately skilled employees are available to deliver products and services.

- Increasing SDC by attracting additional personnel into the tourism industry from within the community or from outside the community via internal or external immigration.

- Increasing SQC by promoting work and careers in the industry and by investing in additional training programmes in order to increase the number of qualified personnel available to the industry.

- Identifying specific areas within tourism (products, services) which face either SDC or SQC (or both) shortages and address these in quantitative or qualitative terms (or both).

- Imposing work quality and minimum remuneration standards (SEC).

What tourism development policy makers require is an openess to ask questions and seek meaningful answers relating to SEC, SDC and SQC at the time when policy shifts in tourism and wider economic development are proposed and when there are plans to seek 
significant changes in markets, products, infrastructure or services - for example, new build hotel investment, new event space, increases in airport capacity, reorientation of marketing spend to new visitor markets - that will require changes to current workforce capacity and capability within a destination. Similarly, changes emanate from developments within other sectors of the economy, especially adjacent services. This, likewise, may provide the basis to engage with political commitments and economic plans to increase visitor numbers by $x$ million or growing visitor spend by US\$ y million through a fuller consideration of what this means in workforce (SEC, SDC and SQC) terms.

Alongside this imperative is the need to understand the challenges that engaging with 'decent work', job quality, capacity and capability issues may pose in the wider social, economic and cultural context of the destination. This is where reference back to Figure 1 is valuable in engaging with policy relationships between the tourism workforce and other areas of key policy consideration that may impact on the capacity, capability and desire of the destination to address SEC, SDC and SQC considerations.

This approach has the potential to create deeper understanding of the associations between policy areas and how these may relate to workforce planning in the services economy, specifically in tourism. This, in turn, may allow for answers to emerge with respect to the 'problems' identified but rarely answered in framing policy around workforce issues in the sector (referring back to Solnet et al 2014 here). Therefore, there is a need for conceptual and practical testing and evaluation of the potential of more macro-oriented analytical approaches aligned to the framework suggested in this paper in order to improve understanding of the workforce and the issues it faces in ensuring the sustainability of the tourism sector. This evaluation will require leadership from the public sector within tourism 
and beyond (including, inter alia, skills development agencies; economic development leadership; culture and heritage interests; complementary economic sectors such as elder are and retail; as well as those involved directly with tourism).

\section{Conclusions}

The argument that drives this paper starts with the neglect of workforce issues in the sustainable business discourse at both academic and professional levels and the consequences that this has for the quality of policy-making with respect to sustainable tourism at a destination level. There is widespread recognition that workforce issues in tourism are a 'problem' while, at the same time, organisations and locations claim the centrality of people to their success (Solnet et al 2015). There is little evidence that the debate or proposed solutions have moved forward significantly over the past 25 years although some engagement between perceived 'problematic areas' in tourism employment and the sustainable HRM narrative is emerging (Gorenak, 2016; Baum et al, 2016b).

The argument followed by this paper, building on the principles of sustainable HRM, can also help to frame the focus of future research in the tourism workforce space. Baum et al (2016a) have demonstrated the paucity of policy-informing research on tourism employment and the sector's workforce with little evidence of critical engagement with the social, economic and cultural context within which they are located. Such themes need to be the focus of a tourism workforce research agenda that moves beyond a search for operational answers to perceived managerial 'problems' to seek contextual understanding and explanation. Such studies could seek to replicate Solnet et al's (2014) analysis of policy formulation for the tourism workforce in Australia and Scotland. The development of 
specific indicators by which to capture a destination's SEC, SDC and SQC as the first step to test whether they are of value beyond the theoretical and conceptual levels would also be of value. Finally, comparative, benchmarking studies, addressing the lessons to be learned from the incorporation of workforce considerations into policy framing across time and space (Rose, 1991) would also be of value in creating better understanding of the issues in this area.

Therefore, this paper advocates a significant change in the way that the complex, multi-lateral relationships between sustainable tourism development, sustainable human resource management, the role of the workforce in tourism and wider domains of social and economic policy are conceptualised. The approach advocated for this is to recognise the importance of capacity, capability and social responsibility issues within workforce policy and planning and how these can be assessed alongside an approach that recognises the inter-dependencies of sector workforce planning with other drivers of the political, social, economic and cultural policy space. These, in turn, can be seen as key pillars in the drive towards the creation of stability and sustainability in workforce terms, making the notion of achieving a decent work culture a realistic proposition for tourism employment. 


\section{References}

Adler, P. A., and P. Adler (2004) Paradise laborers. Hotel work in the global economy. Ithaca: Cornell University Press.

Andriotis, K., and D.R. Vaughan (2004) "The tourism workforce and policy: Exploring the assumptions using Crete as the case study." Current Issues in Tourism 7(1): 66-87.

Autor, D. and D. Dorn (2009) The Growth of Low Skill Service Jobs and the Polarization of the U.S. Labor Market, National Bureau of Economic Research Working Paper 15150, Cambridge, MA: National Bureau of Economic Research.

Axelsson, R., P. Angelstam, E. Degerman, S. Teitelbaum, K. Andersson, M. Elbakidze and M. Drotz (2013).I "Social and Cultural Sustainability: Criteria, Indicators, Verifier Variables for Measurement and Maps for Visualization to Support Planning. "AMBIO 42(2): 215-228.

Bal, M. and S. de Jong. (2017) "From Human Resource Management to Human Dignity Development: A Dignity Perspective on HRM and the Role of Workplace Democracy." In (eds) M. Kostera and M. Pirson. Dignity and Organization, London: Palgrave MacMillan, 173195.

Bartlett, K. R., K. Johnson and I.E. Schneider (2016) “Comparing strategic human resource development approaches for tourism and hospitality workforce planning." Journal of Human Resources in Hospitality and Tourism 15(4): 1-22.

Baum, T. 1994. National tourism policies: Implementing the human resource dimension. Tourism Management, 15(4):259-266.

Baum, T. 1996. "Unskilled work and the hospitality industry: Myth or reality?" International Journal of Hospitality Management, 15(3): 207-209.

Baum, T. 2002. "Skills and training for the hospitality sector: a review of issues." Journal of Vocational Education and Training, 54(3): 343-363.

Baum, T. (2006) Human Resource Management for Tourism, Hospitality and Leisure. An International Perspective. London: Thomson.

Baum, T. (2007) "Human resources in tourism: still waiting for change." Tourism Management 28: 1383-1389.

Baum, T. (2012) Migrant workers in the international hotel industry. Geneva: ILO

Baum, T. (2013) International Perspectives on Women and Work in Hotels, Catering and Tourism. Geneva: ILO.

Baum, T. (2015) "Human resources in tourism: still waiting for change? A 2015 reprise." Tourism Management 50: 204-212. 
Baum, T. and E. Szivas. 2008, HRD in Tourism: a role for government? Tourism Management, 29(4):783-794

Baum, T., A. Kralj, R. Robinson and D. Solnet (2016a) "Tourism Workforce Research: A Review, Taxonomy and Agenda." Annals of Tourism Research 60: 1-22.

Baum, T., C. Cheung, H. Kong, Kralj, A., S. Mooney, H. Nguyen Thi Thanh, S. Ramachandran, M. Dropulic Ruzic and M.L. Siow. (2016b) "Sustainability and the Tourism and Hospitality Workforce: A Thematic Analysis." Sustainability. 8(8) doi:10.3390/su8080809

Bergene, A.C., K. Boluk and E. Buckley. 2015 "Examining the opportunities and challenges of union organisation within the hospitality industry." In (eds) D. Jordhus-Lier and A.

Underthun, A Hospitable World? Organising work and workers in hotels and tourist resorts. London: Routledge, 195-212.

Birch, S., T. Mason, M. Sutton and W. Whittaker. 2013. "Not enough doctors or not enough needs? Refocusing health workforce planning from providers and services to populations and needs." Journal of Health Services Research \& Policy 18(2): 107-113.

Birch, S., G. Tombin Murphy, A. MacKenzie and S. Cummings. 2015. "In place of fear: aligning health care planning with system objectives to achieve financial sustainability." Journal of Health Services Research \& Policy 20(2): 109-114.

Boardman, J., A. Johns, D. Petre and W. Weinz 2015. Opportunities and Challenges in the Promotion of Decent Work in Hotel Global Supply Chains. Geneva: ILO.

Booth, S. and K. Hamer 2007. "Labour turnover in the retail industry: Predicting the role of individual, organisational and environmental factors." International Journal of Retail \& Distribution Management 35(4): 289 - 307.

Broadridge, A., G. Maxwell and S. Ogden 2007. "13_2_30: Experiences, perceptions and expectations of retail employment for Generation Y." Career Development International 12(6): $523-544$.

Buller, P. and G. McEvoy. 2016. "A Model for Implementing a Sustainability Strategy through HRM Practices." Business and Society Review 121(4): 465-495.

Burns, P. M. 1997. "Hard-skills, soft-skills: Undervaluing hospitality's 'Service with a Smile'." Progress in Tourism and Hospitality Research, 3: 239-248.

Christen, M. and S. Schmidt 2011. "A formal framework for conceptions of Sustainability A theoretical contribution to the discourse in sustainable development." Sustainable Development, 20: 400-410.

Cobble, D. 1991. "Organizing the Postindustrial Work Force: Lessons from the History of Waitress Unionism". ILR Review, 44(3): 419-436. 
Cohen, E., Taylor, S., \& Muller-Carmen, M. (2012). HRM's role in corporate social and environmental sustainability. Alexandria, Virginia: SHRM Foundation.

Coyle-Shapiro, J., and I. Kessler, I. 2000. "Consequences of the psychological contract for the employment relationship: A large scale survey. Journal of management studies". 37(7): 903930.

Crettenden, I., M. McCarty, B. Fenech, T. Heywood, M. Taitz, and S. Tudman 2014. "How evidence-based workforce planning in Australia is informing policy development in the retention and distribution of the health workforce." Human Resources for Health, 12(7): 113.

Darcy, C., A. McCarthy, J. Hill and G. Grady 2012. "Work-life balance: One size fits all? An exploratory analysis of the differential effects of career stage". European Management Journal 30(2): 111- 120.

Davidson, M. and Y. Wang. 2011. "Sustainable Labor Practices? Hotel Human Resource Managers Views on Turnover and Skill Shortages." Journal of Human Resources in Hospitality And Tourism. 10(3): 235-253.

De Beer, A., C. Rogerson and J. Rogerson 2014. "Decent Work in the South African Tourism Industry: Evidence from Tourist Guides." Urban Forum 25(1): 89-103.

Dinica, V. 2009. "Governance for sustainable tourism: a comparison of international and Dutch visions." Journal of Sustainable Tourism 17(5): 583-603.

Duncan, T., D. Scott and T. Baum 2013. "The mobilities of hospitality work: an exploration of issues and debates." Annals of Tourism Research 41(4): 1-19.

Ehnert, I. 2009. Sustainable Human Resource Management. Berlin: Springer.

Ehnert, I. and W. Harry 2012. "Recent developments and future prospects on sustainable human resource management: Introduction to the special issue." Management Revue 23(3): 221-238.

Ehnert, I., W. Harry and K. Zink. 2014. "Sustainability and HRM." In (eds) I. Ehnert, W. Harry and K. Zink. Sustainability and HRM, Berlin: Springer, 3-34.

Ehnert, I., S. Parsa, I. Roper, M. Wagner and M. Muller- Camen. 2016. "Reporting on sustainability and HRM: a comparative study of sustainability reporting practices by the world's largest companies". The International Journal of Human Resource Management, 27(1): 88-108.

Esichaikul, R. and T. Baum. 1998. "The case for government involvement in human resource development: A study of the Thai hotel industry". Tourism Management, 19(4):359-370. 
Fujimoto, Y., F. Azmat and C. Härtel. 2013. "Gender perceptions of work-life balance: management implications for full-time employees in Australia". Australian Journal of Management 38(1): 147-170.

Gangani, N., G. McLean and R. Braden. 2006. "A Competency-Based Human Resource Development Strategy". Performance Improvement Quarterly 19(1): 127-139.

Garavan, T. N., and D. McGuire 2010. "Human resource development and society: Human resource development's role in embedding corporate social responsibility, sustainability, and ethics in organizations". Advances in Developing Human Resources 12(5): 487-507.

Glenn, E. 1992. "From Servitude to Service Work: Historical Continuities in the Racial Division of Paid Reproductive Labor". Signs, 18(1): 1-43.

Goos, M. and A. Manning 2007. "Lousy and lovely jobs. The rising polarization of work in Britain." The Review of Economics and Statistics 89(1): 118-133.

Goos, M., A. Manning and A. Salomons 2009. "Job polarization in Europe." American Economic Review: Papers and Proceedings 99(2): 58-63.

Gorenak, M. 2016. "Sustainable development of careers in tourism." Teorija in Praksa, 53(4): 959-975.

Gregg, P., G. Kelly, J. Dowden, F. Kendrick, F.O'Grady, A. Robb, J. Unwin, J. Watt, and R. Wickham. 2016. Closing the Gap::A Living Wage that means families don't go short. London: Living Wage Foundation.

Gallouj, F., K. M. Weber, M. Stare and L. Rubalcabe. 2015."The futures of the service economy in Europe: A foresight analysis". Technological Forecasting and Social Change, 94:80-96.

Gursoy, D., C. Geng-Qing Chi and E. Karadag. 2013. "Generational differences in work values and attitudes among frontline and service contact employees." International Journal of Hospitality Management. 32(1): 40-48.

Hargreaves, A., and D. Fink, 2006. Sustainability leadership. San Francisco, CA: Jossey-Bass.

Hart, C., G. Stachow, A. Farrell and G. Reed 2007. "Employer perceptions of skills gaps in retail: issues and implications for UK retailers." International Journal of Retail \& Distribution Management 35(4): $271-288$.

Howe, A., D. King, J. Ellis, Y. Wells, Z. Wei and K. Teshuva 2012. "Stabilising the aged care workforce: an analysis of worker retention and intention." Australian Health Review 36(1): 83-91.

Human Science Research Council. 2017. Strategic framework for tourism human resource and skills development in South Africa. A report for the National Department of Tourism and 
the Culture, Arts, Tourism, Hospitality and Sports Sector Education and Training Authority. Pretoria: Human Sciences Research Council.

International Labour Organization (ILO) 2012. Decent work indicators. Concepts and Definitions. Geneva: ILO.

International Organization for Migration (IOM). 2005. Labour Migration in Asia Protection of Migrant Workers, Support Services and Enhancing Development Benefits. Geneva: IOM

Janta, H., L. Brown, P. Lugosi and A. Ladkin 2012. "Migrant relationships and tourism employment." Annals of Tourism Research 38(4): 1322-1343.

Jee, M. 2016. "Automation becoming impossible to resist" MHD Supply Chain Solutions 46(2): 32.

Jithendran, K. J. and T. Baum 2000. "Human resources development and sustainability - The case of Indian tourism." International Journal of Tourism Research 2: 403-421.

Joppe, M. 2012. "Migrant workers: challenges and opportunities in addressing tourism labour shortages." Tourism Management 33: 662-671.

Kirkegaard, J. 2007 Accelerating decline in America's high-skilled workforce: Implications for immigration policy, Vol 84. Washington, DC: Peterson Institute for International Economics.

Knox, A., C. Warhurst, D. Nickson and E. Dutton. 2015. "More than a feeling: using hotel room attendants to improve understanding of job quality." The International Journal of Human Resource Management, 26(12): 1547-1567.

Kong, H., C. Cheung and H. Song, H. 2012. "Determinants and outcome of career competencies: Perspectives of hotel managers in China". International Journal of Hospitality Management 31)3):712-719.

Kramar, R. 2014. "Beyond strategic human resource management: is sustainable human resource management the next approach?" The International Journal of Human Resource Management 25(8): 1069-1089.

Kuchinke, K. P. 2010. "Human development as a central goal for human resource development". Human Resource Development International 13(5): 575-585.

Ladkin, A. 2011. "Exploring tourism labor", Annals of Tourism Research, 38(3): 1135-1155.

Lange, T. 2016. "Editorial: Sustainable HRM and employee well-being: an empirical agenda." International Journal of Manpower, 37(6): 918 - 923.

Larsen, C. and Lauxen, O. 2014. "Integration of local knowledge in health workforce planning." European Journal of Public Health 24: 244-245. 
Lee, J-S., K-J. Back and E. Chan 2015 "Quality of work life and job satisfaction among frontline hotel employees: A self-determination and need satisfaction theory approach". International Journal of Contemporary Hospitality Management, 27(5): 768 - 789.

Liebowitz, J. 2010. "The Role of HR in Achieving a Sustainability Culture." Journal of Sustainable Development 3(4): 50-57.

Lub, X., M. Nije Bijvank, P. Matthijs Bal, R. Blomme and R.Schalk, 2012. “Different or alike? Exploring the psychological contract and commitment of different generations of hospitality workers". International Journal of Contemporary Hospitality Management, 24(4):553-573.

Lynham, s. and P. Cunningham. 2006. "National Human Resource Development in Transitioning Societies in the Developing World: Concept and Challenges". Advances in Developing Human Resources 8(1): 116-135.

Martin, B. and D. King 2008. Who cares for older Australians? A picture of the residential and community based aged care workforce. Adelaide: National Institute of Labour Studies, Flinders University.

McDowell, L., A. Batnitzky and S. Dyer. 2007. Division, segmentation, and interpellation: The embodied labors of migrant workers in a greater London hotel. Economic Geography, 83(1),: $1-25$.

Mclean, G.N. 2004. "National Human Resource Development: What in the World Is It?" Advances in Developing Human Resources 6(3): 269-275.

McLean, G. N. 2012. "Invited response observations on modelling NHRD strategy". Human Resource Development Review, 11: 430-436.

Mehta, K and P. Chugan. 2015. "Green HRM in Pursuit of Environmentally Sustainable Business". Universal Journal of Industrial and Business Management, 3(3):74-81.

Miller, G., K. Rathouse, C. Scarles, K. Holmes and J. Tribe 2010. "Public understanding of sustainable tourism." Annals of Tourism Research 37(3): 627-45.

Nickson, D., C. Warhurst and A. Witz. 2003. "The labour of aesthetics and the aesthetics of organization". Organization, 10(1): 33-54.

Okumus, F., K. Karamustafa, M. Sariisik, S. Ulama and O. Turkay. 2016. "Career paths of hotel general managers in Turkey". Asia Pacific Journal of Tourism Research, doi.org/10.1080/10941665.2016.1140660

Ono, T., G. Lafortune and M. Schoenstein 2013. Health Workforce Planning in OECD Countries: A Review of 26 Projection Models from 18 Countries. OECD Health Working Papers, No. 62. Paris: OECD Publishing.

Perry, E. 2013, Apr. "HOW TO... ...create a sustainable workforce." Caterer \& 
Hotelkeeper, 203: 37.

Poulston, J. 2008. "Rationales for employee theft bin hospitality: excuses, excuses." Journal of Hospitality and Tourism Management, 15:49-58.

Rajan, R. G., and J. Wulf 2006. "Are perks purely managerial excess?" Journal of Financial Economics 79: 1-33.

Rana, S. and A. Ardichvili 2015. "Cambodia and the ASEAN economic community: Opportunities, challenges, and implications for human resource development". Reconsidering Development, 3:38-55.

Rimanoczy, I., and T. Pearson. 2010. "Role of HR in the new world of sustainability". Industrial and Commercial Training 42(1):11-17.

Robinson, R. N. 2013. "Darker still: Present-day slavery in hospitality and tourism Services". Hospitality \& Society, 3(2): 93-110.

Rose, R. 1991. What is lesson-drawing? Glasgow: Centre for the Study of Public Policy.

Rubery, J., G. Hebson, D. Grimshaw, M. Carroll, L. Smith, L. Marchington and S. Ugarte 2011. The recruitment and retention of a care workforce for older people. Manchester: European Work and Employment Research Centre (EWERC), University of Manchester.

Ruetschlin, C. 2013. "Rethinking Retail: How Investments in the Retail Workforce Can Affect Families, Firms, and Economic Growth." Challenge 56(2): 31-52.

Scully-Ross, E. 2012). "Human resource development and sustainability: Beyond sustainable organizations". Human Resource Development International, 15(4): 399-414.

Shaw, G., and A. Williams. 1994. Critical issues in tourism: A geographical perspective. Oxford: Blackwell

Singh, S. 1997. "Developing human resources for the tourism industry with reference to India." Tourism Management 18(5): 299-306.

Solnet, D., D. Nickson, R. Robinson, A. Kralj and T. Baum 2014. "Discourse About Workforce Development in Tourism-An Analysis of Public Policy, Planning, and Implementation in Australia and Scotland: Hot Air or Making a Difference?" Tourism Analysis 19(5): 609-623.

Solnet, D., A. Kralj and T. Baum 2015. "360 degrees of pressure: the changing role of the HR professional in the hospitality industry." Journal of Hospitality and Tourism Research 39(2): 271-292.

Solnet, D., T. Baum, R. Robinson and L. Lockstone-Binney, 2015. "What about the workers? Roles, scripts and skills for employees in the hotels of the future." Journal of Vacation Marketing doi: 10.1177/1356766715617403. 
Sehnbruch, K., B. Burchell, N. Agloni and A. Piasna. 2015. "Human Development and Decent Work: Why some Concepts Succeed and Others Fail to Make an Impact." Development and Change 46(2): 197-224.

The Guardian. 2016. "Michel Roux Jr admits restaurant staff get no share of service charge." The Guardian, $16^{\text {th }}$ December 2016, accessed at https://www.theguardian.com/lifeandstyle/2016/dec/15/michel-roux-jr-restaurant-staffno-share-service-charge-le-gavroche?CMP=share btn link, $16^{\text {th }}$ December 2016.

Tisdell, C. 2000. Sustainable development of human resource capital. Principles of sustainable development, Vol. 1. Encyclopedia of Life Support Systems (EOLSS), Developed under the Auspices of the UNESCO, Eolss Publishers, Paris, France, Accessible at http://www.eolss.net/sample-chapters/c13/e1-46a-02-02.pdf (04.11.2016).

Torres-Delgado, A. and F. Lopez Palomeque 2012. "The growth and spread of the concept of sustainable tourism: The contribution of institutional initiatives to tourism policy." Tourism Management Perspectives 4: 1-10.

Ulrich, D., and N.Smallwood, 2013. Leadership sustainability. New York: McGraw Hill.

United Kingdom Commission for Employment and Skills (UKES) 2014. The Labour Market Story: Skills For the Future, Briefing Paper. London: UKES.

United Nations 2015. "Transforming our world: the 2030 Agenda for Sustainable Development." https://sustainabledevelopment.un.org/content/documents/21252030\%20Agenda\%20for\% 20Sustainable\%20Development\%20web.pdf (accessed 10 ${ }^{\text {th }}$ May 2016).

United Nations World Tourism Organization (UNWTO) (nd) Sustainable Tourism. Definition. Accessed at http://sdt.unwto.org/content/about-us-5, 13 ${ }^{\text {th }}$ October 2017.

University of the Aegean 2002. Defining, Measuring and Evaluating Carrying Capacity in European Tourism Destinations. Athens: University of the Aegean.

Voegtlin, C., and M. Greenwood 2016. "Corporate social responsibility and human resource management: A systematic review and conceptual analysis". Human Resource Management Review, 26(3), 181-197.

Waas, T., J. Hugé, T. Block, T. Wright, F. Benitez-Capistros and A. Verbruggen 2014. "Sustainability Assessment and Indicators: Tools in a Decision-Making Strategy for Sustainable Development." Sustainability 6(9): 5512-5534.

Westwood, A. 2002. Is new work good work? London: The Work Foundation.

Wilcox, T. 2006 "Human Resource Development as an Element of Corporate Social Responsibility." Asia Pacific Journal of Human Resources, 44: 184-196. 
Wood, R. 1997. Working in hotels and catering (2nd ed.). London: International Thomson.

Zaugg, R. J., A. Blum and N. Thom 2001. Sustainability in Human Resource Management. Working paper No. 51, Institute for Organisation and Personnel. Bern: University of Bern.

Zeng, Z. and B. Honig. 2016. "A study of living wage effects on employees' performancerelated attitudes and behaviour." Canadian Journal of Administrative Sciences, DOI: 10.1002/CJAS.1375 


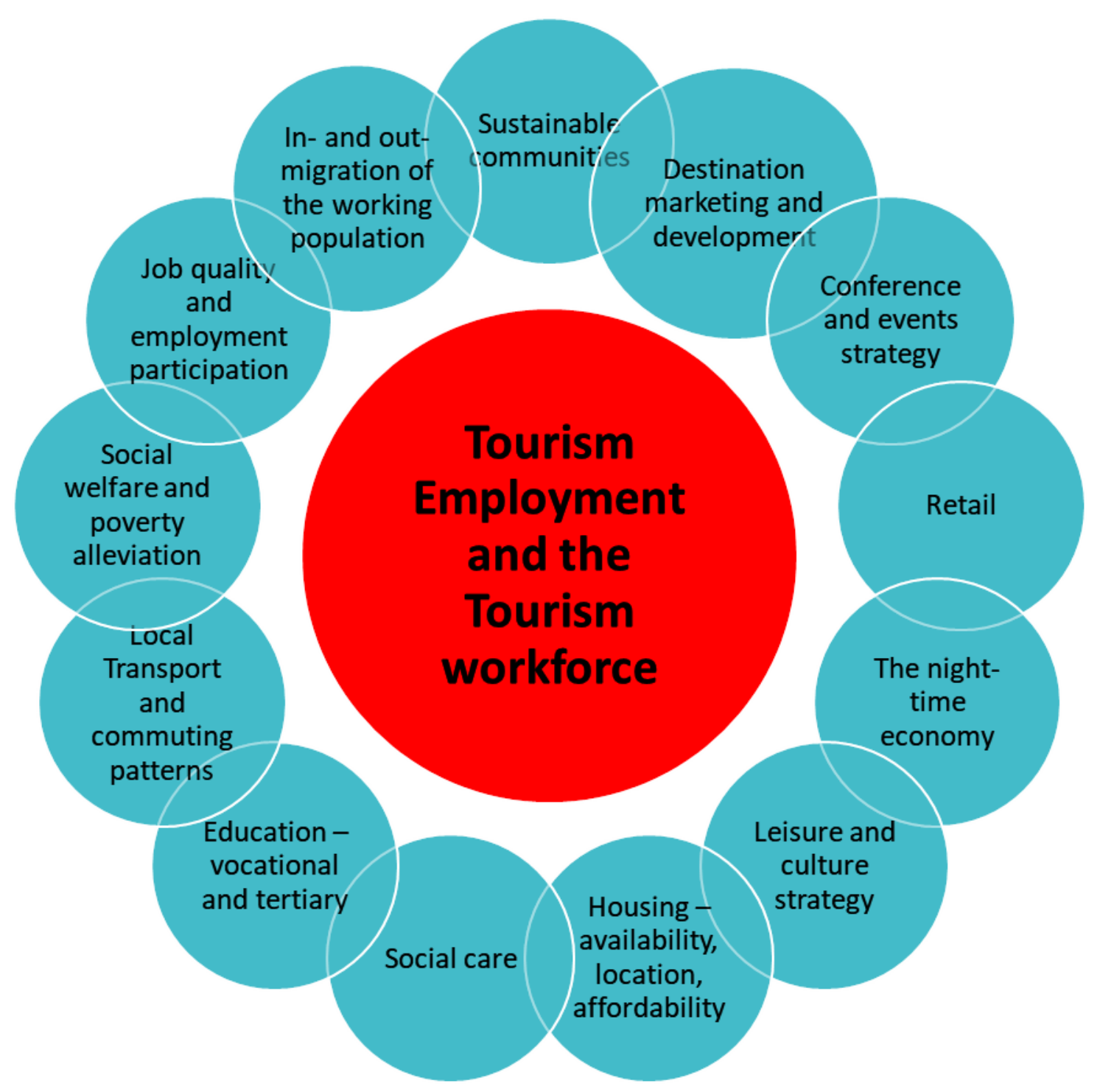

Figure 1: Indicative relationships between the tourism employment and the tourism workforce and the wider policy environment at the level of a destination/ country 